\title{
REGENERATION OF POST-MILITARY AREAS IN POLAND
}

\author{
WOJCIECH JARCZEWSKI, MICHAŁ KURYŁO
}

\author{
Institute of Urban Development \\ Cieszyńska 2, 30-015 Kraków, Poland \\ e-mail: jarczewski@poczta.fm mkurylo@irm.krakow.pl
}

\begin{abstract}
The Polish public space was enriched after 1990 by ca 77,600 ha of post-military land of which 11,861 ha are located in towns and cities. Compact redevelopment areas (former military garrisons, with barracks, hospitals, warehouses, fuel stations etc.) are located in 107 towns. In total, such areas occupy 10,000 ha. In addition, 5 former proving grounds were released and they are not currently used by the Army. The total area of that land is 49,933 ha. Also, 48 former airfields were given up, with the total surface area of 17,000 ha. Such a large surface area has been exceptionally important in the context of land resources (Jarczewski 2009).

Key words: regeneration, post-military areas, Military Property Agency, new users
\end{abstract}

\section{INTRODUCTION}

After 1990, the Polish public and private space was increased by ca. 56,000 ha of land which was surrendered by the Russian Federation Army (until 1993) and another 20,000 ha handed over as a result of the reduction of the number and sizes of the Polish Army bases. Consequently, the military areas, which used to be marked with white spots on the maps issued under the People's Republic of Poland regime, obtained a "civilian" character.

The Post-military areas in Poland have not been an object of a synthetic description yet. This study is an attempt at drawing some conclusions of about a dozen of years of our experience with the transformation of land abandoned by the army.

\section{OBJECTIVE AND SCOPE OF STUDY}

The authors' objective was to analyse the consequences of the release of considerable areas by the Army and re-inclusion of that land in the public space. The attainment of that objective required study and evaluation of the following phenomena: 
1) Scale and quality of post-military areas, taking into account their distribution both in Poland and within specific towns or cities.

2) Scale and directions of the transformations occurring on post-military areas.

3) Potential of post-military areas in the context of their suitability for revival and sustainability of local and regional development.

4) Scale of the degradation of the natural environment on post-military areas and the attempts at land reclamation.

Post-military areas can be divided into several types owing to their general characteristics and original use. They include former:

- Airfields, with infrastructure

- Proving grounds

- Sea ports

- Bases, including e.g. barracks, hospitals, schools, cultural centres, shops, canteens, command and communication centres, garages, warehouses, workshops, transportation infrastructure etc. In addition, the post-Soviet ballistic missile and nuclear weapon sites constitute special types of facilities.

Our research specifically concentrated on the processes occurring within towns and cities, as well as some urban and rural municipalities. To obtain a complete picture, we tried, however, to show rather the issues pertaining to urban post-military areas in a broader and exhaustive context including also rural municipalities where a considerable portion of post-military areas are located due to their surface area.

\section{SOURCES OF INFORMATION AND METHODS OF ANALYSIS}

Our studies were carried out in four basic stages:

1) Review of the existing publications (those concerning all issues related to post-military areas, case studies relating to selected towns and articles from specialized journals).

2) Collection and analysis of source materials which included the following:

- Data on the liquidation of garrisons obtained from the Ministry of National Defence.

- Surveys conducted by the Polish Cities Association in 32 towns and cities.

- Legal acts regulating the principles of transfer and development of post-military areas.

- Statistical data from the Regional Data Bank (BDR) made available by the Central Office of Statistics (GUS).

- Programme documents from municipalities and counties.

- In addition, the central government's programme and strategic documents were found to be important sources of information.

3) Structured telephone surveys in all towns and cities where post-military areas were identified. After such a survey, we requested filling out of a written questionnaire 
on the scale of the problem and the processes related to land development. In total, 150 surveys were conducted in 107 towns, and 49 questionnaires were returned.

4) Analysis of the collected materials, combined with graphical result presentation. Outcomes included about a dozen of tables, maps and graphs produced on the basis of the data collected from the sources indicated above.

\section{TRANSFER OF POST-MILITARY AREAS}

The land surrendered by the Soviet and Polish Armies is subjected to redevelopment in Poland. In some cases, the post-Soviet lands were first taken over by the Polish Army and later excluded from its properties under further restructuring projects. The post-Soviet lands were demilitarised in a very short period, mainly in 1992 and 1993. The withdrawal of the Russian Federation troops started in 1991 when military installations were liquidated in 13 locations (24 in 1992 and 20 in 1993). The last combat detachment of the former Red Army left Poland on 28 October 1992, and the last Russian soldiers crossed the border of the Republic of Poland on their way back home on 18 September 1993 (Szczepański 2005).

The Polish Army left a number of areas owing to restructuring processes. The processes were distributed over a much longer period of time and they are continued presently.

\section{SOVIET BASES}

The Soviet Army (or the Army of the Russian Federation since 1991) was continuously present on the territory of Poland (as part of the Northern Group of the Soviet Army) from 1944 to 1993. The Group's command was located in Legnica.

Top secret documents regulated the numbers of Soviet troops at the level of 62-66 thousand. More than 39 locations were established (Krogulski 2001). During the whole period of the stay of the Soviet Army in Poland, the number of sites was changing. There were 70 of them in 1956 (Wojtyś 2002), 74 in 1958, 76 in 1966, and 59, with the total surface area of more than 70,000 ha, before withdrawal in 1989 (Figure 1). The bases were mostly located on the western territories of Poland, or the so-called regained territories. The barracks and proving grounds abandoned by the Wehrmacht were often occupied and used by the Soviet and Polish Armies.

\section{POLISH BASES}

The process of transformations initiated after 1989 also applied to the Polish Army. Disbanding of the Warsaw Treaty Organization accelerated the process of changes in the geographical locations of the Polish garrisons and their reduction. During the Polish participation in that Organization, the garrisons were located mainly on the western territories. After the Polish departure from the Treaty, the processes of 


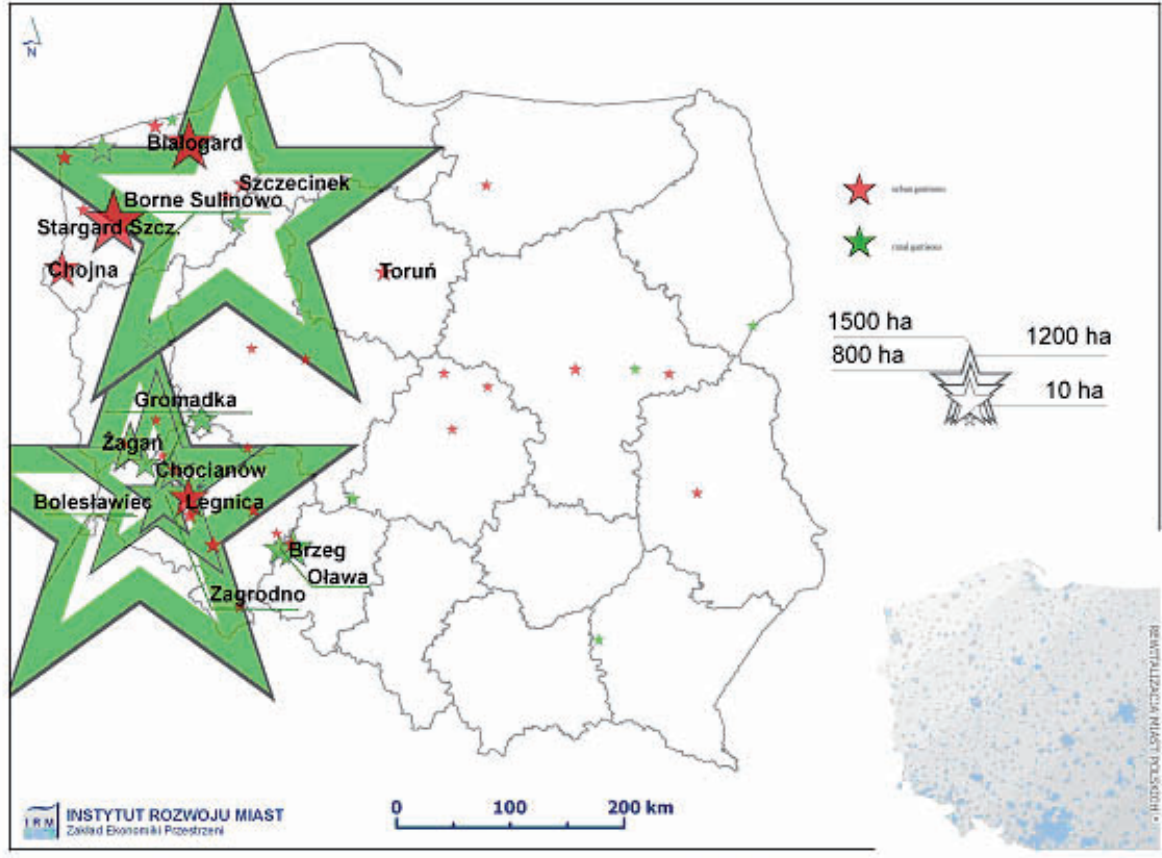

Figure 1. Distribution of the Soviet bases liquidated in 1991-1993 Source: Figures 1-5 own studies.

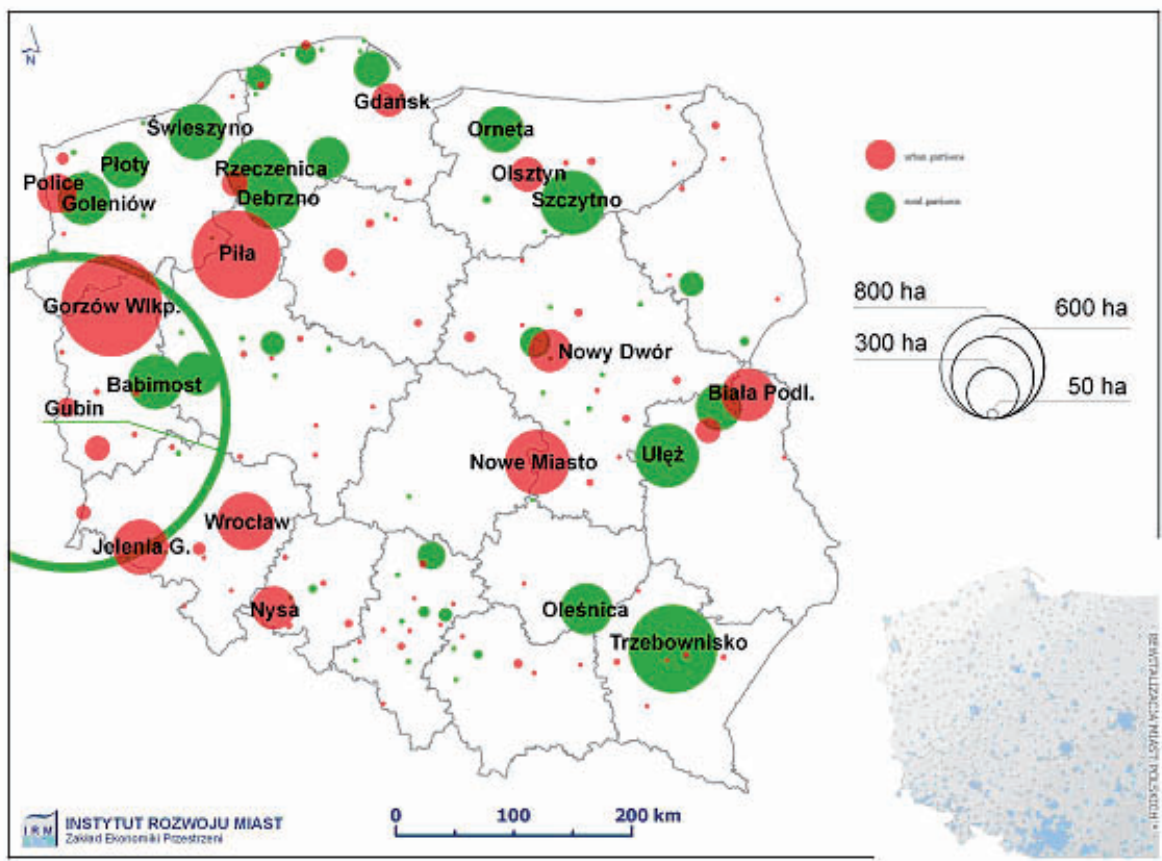

Figure 2. Distribution of the Polish garrisons liquidated after 1990 
base liquidation and transfer of troops from the western territories started. Another breakthrough occurred when Poland became a NATO member in 1999. That fact enforced further restructuring processes and army professionalization. The latter assumed primarily equipping the troops with modern weapon systems which allow for reduction of personnel owing to higher efficiency.

In 2001-2009, the number of troops of the Polish Armed Forces was reduced by 101,000 positions, to reach 102,000 in 2010, according to legal assumptions (Law of reconstruction...2009). Garrisons in 97 Polish towns were liquidated in parallel to the reduction of personnel. In 1999-2007, the Military Property Agency took over real estates, with the total surface area of 20,700 ha, and 8,982 structures from the Ministry of Defence. The book value of the properties was estimated at 3.8 billion Polish zlotys.

The Polish Armed Forces development programme, approved recently, decided that 25 more garrisons will be liquidated until 2012 (101 sites will remain), and the Army will surrender 45,000 ha of land, or $20 \%$ of the current land resources (Lentowicz 2009).

The Polish Army restructuring processes led to the change of the employment structure in many Polish towns (Figure 2). In addition, the problem of availability of post-military areas occurred, and specific real estates had to be adopted for civilian use.

\section{SOCIAL AND ECONOMIC CONSEQUENCES OF GARRISON LIQUIDATION}

In the report on the social and economic consequences of the liquidation of the garrisons treated by the Programme, it was estimated that 12,989 professional soldiers and civilian workers lost their jobs as a result of restructuring projects conducted in 2001-2006. The report did not include the figures indicating an increase of unemployment associated with the liquidation of the businesses serving the garrisons (Table 1).

In 2004, unemployment increased faster than in the whole country in 17 counties (from among 51 in which garrisons were liquidated in 2001-2004). In 10 counties, a considerable increase was recorded. In the first half of 2005, 25 counties where garrisons and military units had been liquidated in 2001-2004, were recognized as the areas threatened by structural unemployment. We can estimate that in the following regions: Wielkopolskie, Lubuskie, Dolnośląskie and Warmińsko-Mazurskie, liquidation of military units could have caused the increase of unemployment by ca. $0.3-0.4$ of the percentage point, while the same causes affected the unemployment rate in the remaining 12 regions by less than 0.1 of the percentage point (Social and Economic... 2004). 
Table 1. Jobs liquidated as a result of the liquidation of the garrisons subjected to the "20012006 Programme"

\begin{tabular}{|l|c|c|c|}
\hline \multirow{2}{*}{\multicolumn{1}{|c|}{ Region }} & \multicolumn{3}{|c|}{ Liquidated jobs } \\
\cline { 2 - 4 } & Professional soldiers & Civilian workers & Total \\
\hline Podkarpackie & 101 & 29 & 130 \\
\hline Małopolskie & 88 & 173 & 261 \\
\hline Podlaskie & 52 & 231 & 283 \\
\hline Śląskie & 311 & 33 & 344 \\
\hline Lubelskie & 218 & 150 & 368 \\
\hline Łódzkie & 395 & 75 & 470 \\
\hline Świętokrzyskie & 418 & 96 & 514 \\
\hline Opolskie & 411 & 194 & 605 \\
\hline Zachodniopomorskie & n.a & n.a & 613 \\
\hline Mazowieckie & 300 & 323 & 623 \\
\hline Kujawsko-pomorskie & 208 & 524 & 732 \\
\hline Pomorskie & 589 & 171 & 760 \\
\hline Warmińsko-mazurskie & 300 & 596 & 896 \\
\hline Dolnośląskie & 842 & 656 & 1498 \\
\hline Lubuskie & 1689 & 748 & 2437 \\
\hline Wielkopolskie & 1230 & 1205 & 2455 \\
\hline$\sum$ & - & - & 12989 \\
\hline
\end{tabular}

Source: Social and economic consequences of the liquidation of garrisons subjected to the "Programme of reconstruction and technical modernization of the Polish Armed Forces in 2003-2006, with updates for 2003-2008" 2004.

\section{TRANSFORMATIONS OF POST-MILITARY AREAS}

Post-military properties were adopted for civilian uses to a large extent. Refurbished barracks became interesting housing projects and many buildings were occupied by public institutions, even churches. Various structures, garages and warehouses were taken over by businesses. Some airports were included in the civil aviation network, while others were turned into capital investment zones.

Local governments were not always capable of handling the newly received properties. When a rural municipality, composed mostly of single-family houses, suddenly received a "town", such urban properties exceeded local development capabilities. The municipalities quickly sold the real estates, often to random entities at low prices, or it also happened that the property deteriorated. The expectations that real estates would be more profitable in the future were not always fulfilled. Interest in properties located outside towns was not, so common as it was expected. The pro- 
cess matched economic transformations that released many other facilities worthy of capital investments. Small businesses were buying large warehouses, without being able to use them (Szczepański 2005).

Post-military areas in Poland were and have been the objects of transformation processes consisting in adoption for civilian uses. The identification of such processes, with their naming and assignment to certain categories, allowed us to produce a complete picture of the problem of post-military areas in Poland.

- Considering the following:

- Nature of post-military lands and facilities;

- Location of post-military areas within towns;

- Needs of towns and municipalities;

- Changing social and economic conditions;

at least 9 basic directions of post-military area transformation were developed:

1. New town

2. New (old) town borough

3. Capital investment zone

4. Housing estates

5. Educational facilities

6. Public administration and other public facilities

7. Airports

8. Tourism and recreation

9. Land reclamation

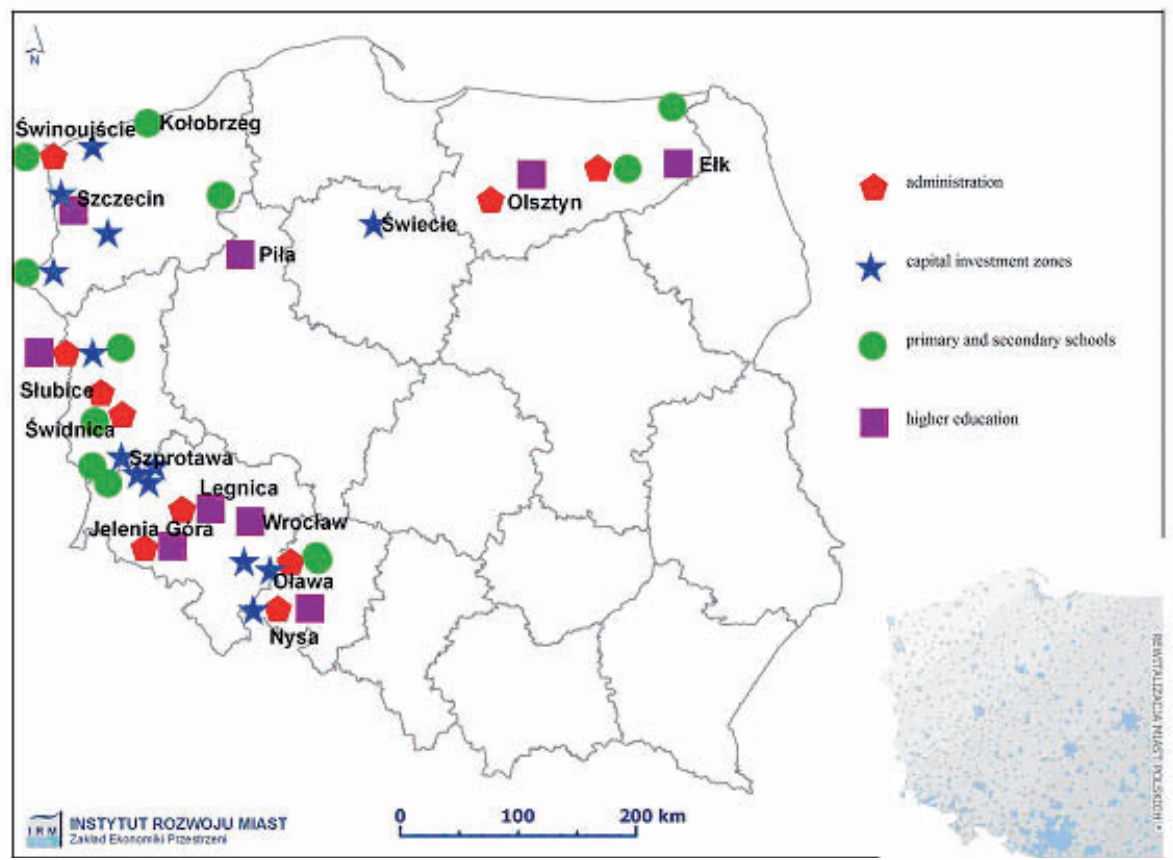

Figure 3. Use of post-military areas and facilities in towns 


\section{NEW TOWN: BORNE SULINOWO}

Military garrisons were often located far from the existing urban areas, which allowed to maintain confidentiality of activities and reduce inconveniences associated with the military unit's activities. The Soviet units often occupied abandoned post-German garrisons and proving grounds, especially since their locations mainly on the so-called Polish regained territories in western Poland were suitable for Soviet strategic purposes. Such garrisons were later developed until 1990 and supplemented with required technical infrastructure, being partly independent from the existing Polish service networks. Several of such post-Soviet garrisons constituted the resources from which new towns could be built. That process was successful in one case only: Borne Sulinowo, and the town received municipal rights as early as on 2 October 1993. The nearby Kłomino (Gródek) was not so lucky. It was composed of groups of barracks which were deteriorating, although they formally belonged to the municipality of Borne Sulinowo. All other garrisons became parts of local municipalities, towns or cities.

The Borne Sulinowo garrison was the largest concentration of the Soviet Army in Poland. One division, two mechanized regiments, a tank regiment and a battalion, an artillery regiment, an anti-aircraft squadron, army engineers', supply, medical and reconnaissance battalions, a combat and tactical missile brigade, and a fuel warehouse were located there. In total, about 25,000 troops were deployed in the garrison, and the unit included a proving ground of 18,000 ha. The Army left 370 buildings which became the basis for founding of a new civilian town.

The real estates taken over by the State Treasury in Borne Sulinowo were quickly commercialised in a large proportion. A small proportion of real estates was transferred to people as part of the compensation for property left on the former Polish eastern territories. The municipality took over some of the properties for public purposes: the Town Office, the Social Welfare Centre, schools, sports halls and a waste treatment plant. Several buildings were occupied by the Polish Mail, the Forest Department and the Silesian University (for a recreation centre). The municipality was trying to sell the majority of the remaining buildings, if not qualified for demolition, to public institutions and private investors. Most of the properties were sold by 1999 .

The transformations which took place in Borne Sulinowo can be treated as a moderate success. A new town was created, with the population of more than 4,600 people, and the number is slowly increasing. The majority of valuable buildings were occupied, and it was possible to put ecological hazards under control by liquidation or removal of the main sources of pollution. The land was generally cleared of unexploded shells. The resources received by the municipality from the central government, as well as various capital investments by government agencies and institutions, supplemented by the municipality's resources, allowed for a fairly regular operation of the town and admission of new "settlers". Presently, the town and the municipality are trying to promote themselves as a tourist and recreation area. 
A considerable proportion of properties are still available, and huge resources are required for development.

\section{NEW (OLD) TOWN BOROUGHS}

The garrisons located in a small distance from towns or those within towns were found to be fairly attractive. The facilities located within cities or towns, especially county or regional centres, were quite quickly redeveloped. Buildings found buyers who were able to cover at least some proportion of repair costs. Also municipalities repaired former barracks from their own resources to prepare them for council housing purposes. Staff, training and hospital buildings were tuned into such public institutions as schools or hospitals. In Ostrów Wielkopolski, the Central Penitentiary Service Management has been conducting intense negotiations to take over the structures left by the Army and turn them into a prison. In some cases, the original function of the military buildings were maintained (e.g. the court house in Legnica).

Garages, hangars and other similar structures located in towns or in the suburbs became attractive facilities for businesses. In the majority of the towns from which the military units withdrew, non-regulated ownership matters remained to be problems, and the Military Property Agency was not eager to hand their properties over after 1996, which resulted in property deterioration and loss of value.

\section{CAPITAL INVESTMENT ZONES}

In at least about a dozen of towns, post-military areas were used as capital investment zones on a larger scale than just conversions of the existing facilities. Large and flat lands, equipped with transportation infrastructure and often developed with basic services, offered interesting locations for capital investments by both local and foreign businesses.

Local governments tried to acquire new investors in order to make up for the lost military jobs at least partly. Some towns prepared comprehensive offerings for a large number of potential investors by creating capital investment zones. As a result of our research, we identified such initiatives in 13 municipalities. In

Table 2. Capital investment areas belonging to Special Economic Zones

\begin{tabular}{|l|l|l|c|}
\hline \multicolumn{1}{|c|}{ Lp. } & \multicolumn{1}{|c|}{ Municipality } & \multicolumn{1}{|c|}{ Special Economic Zone } & Surface (ha) \\
\hline 1. & Stargard Szczeciński & Podstrefa Pomorskiej SEZ & 150 \\
\hline 2. & Gromadka & Podstrefa Legnickiej SEZ & 157 \\
\hline 3. & Przemków & Podstrefa Legnickiej SEZ & 7,0874 \\
\hline 4. & Słubice & Podstrefa Kostrzyńsko-Śłubickiej SEZ & 169,78 \\
\hline 5. & Tomaszowo & Podstrefa Lódzkiej SEZ & 200 \\
\hline 6. & Szprotawa & Podstrefa Wałbrzyskiej SEZ & 2,6 \\
\hline 7. & Police & Podstrefa Kostrzyńsko-Słubickiej SSE & 15 \\
\hline
\end{tabular}

Source: own studies. 
the majority of cases, they were placed on the areas of former Soviet bases (10 out of 13 locations). Several of them were subjected to tax exemptions applicable to Special Economic Zones (Table 2).

\section{HOUSING ESTATES}

One of the most frequent methods of post-military structure redevelopment was the adoption of buildings for housing purposes. The personnel barracks often required small refurbishment, especially in the case of the former Polish Army facilities. As to the former Soviet facilities, the repairs required considerable resources owing to poor technical condition of the majority of structures. Some single-family residences occupied by former commanders were exceptions in that respect. The Soviet Army constructed large-panel blocks of flats (mostly the Leningrad type) for their needs, and such buildings were suitable for conversion.

In 32 towns, former military facilities were designed for housing purposes at least partially. In addition to the adaptation of the existing buildings, suitable conditions existed for the construction of new houses in some locations.

In fact, we can distinguish several directions of redevelopment of former military properties for housing purposes:

- Multi-family houses; single blocks of flats or housing estates.

- Council housing.

- Social housing.

- Social Building Associations.

- Refugee Camp for Chechen refugees in Czerwony Bór.

- Adaptation of building for prisons.

During our study, we identified adaptation of 342 former military buildings for housing purposes. They were turned into 9,235 flats.

\section{EDUCATIONAL FACILITIES}

Educational institutions often participated in the regeneration processes on postmilitary areas. Barracks or former military academies were adopted for the needs of primary, secondary and tertiary schools. Large buildings and former military staff structures were turned mainly into colleges. The buildings were adopted for teaching and housing purposes (dormitories) or turned into sports and recreational facilities (gymnasiums).

The buildings of the Warmińsko-Mazurski University and the Stubice external faculty in of the Adam Mickiewicz University in Poznań were placed in the former military facilities. A similar project was implemented by the Technical University of Szczecin. State Professional Colleges were relocated to such teaching and housing facilities in several other municipalities.

Primary and secondary schools were moved to refurbished buildings in many towns. Our estimated data indicated that about 220 former military buildings were adopted for educational purposes. 


\section{PUBLIC ADMINISTRATION AND OTHER PUBLIC FACILITIES}

Some of the buildings taken over from the military units were adopted for various public administration agencies. That also concerned especially stylish houses located in downtown areas. Such use was quite natural because the State Treasury became the first civilian owner of the former military properties, and the local Governors selected interesting buildings for the government administration. In many cases, properties were taken over by municipalities, which also selected some buildings suitable for local community purposes. Such buildings were often turned into town halls etc.:

- Town and municipality offices,

- County offices,

- Courts and Public Prosecutor Agencies.

The number of post-military buildings adopted for public purposes is estimated at 91 . In addition, dozens of structures were turned into office buildings designed for the Social Security Insurance Company, Customs Offices, Polish Mail, or the Woliński National Park.

\section{AIRFIELDS}

During our research, we identified in Poland 48 airfields which stopped to fulfil their military purposes in whole or in part after 1990 (Figure 4). Neither of the former 14 Soviet airfields has been converted into a civilian facility of local or regional importance. Some of them are used, however, by local Flying Clubs (in Koszalin and

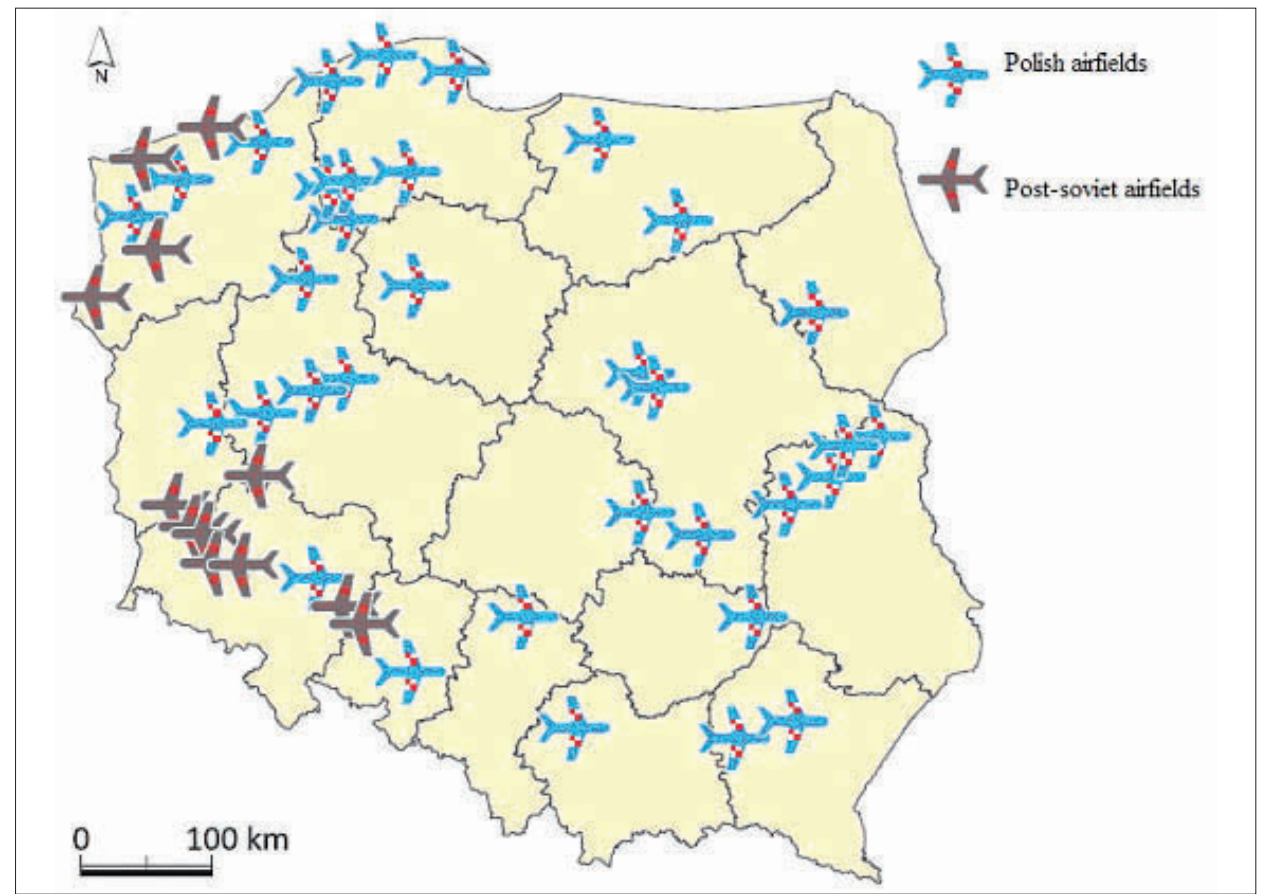

Figure 4. Distribution of former military airfields 
Skarbimierz). Other post-Soviet airfield facilities were turned into:

- Housing estates located in former barracks

- Capital investment zones

- Arable land

- Forests

- Car racing track.

The airfields that were previously used or are currently partly used by the Polish Air Force present a considerable development potential for aviation.

Among the 34 former military airfields, identified in the report, 5 are jointly used for civilian and military purposes. The present civilian sections were previously used only by the Air Force, so they can be recognized as post-military areas. Another category entails 5 civilian airports which were organized on the basis of the properties transferred by the military authorities to local governments. The most interesting municipalities, from the viewpoint of the report under discussion, are those which plan to develop civilian airports in former Air Force facilities (Figure 5). Besides, wind farms are planned to be constructed on 5 former military airfields.

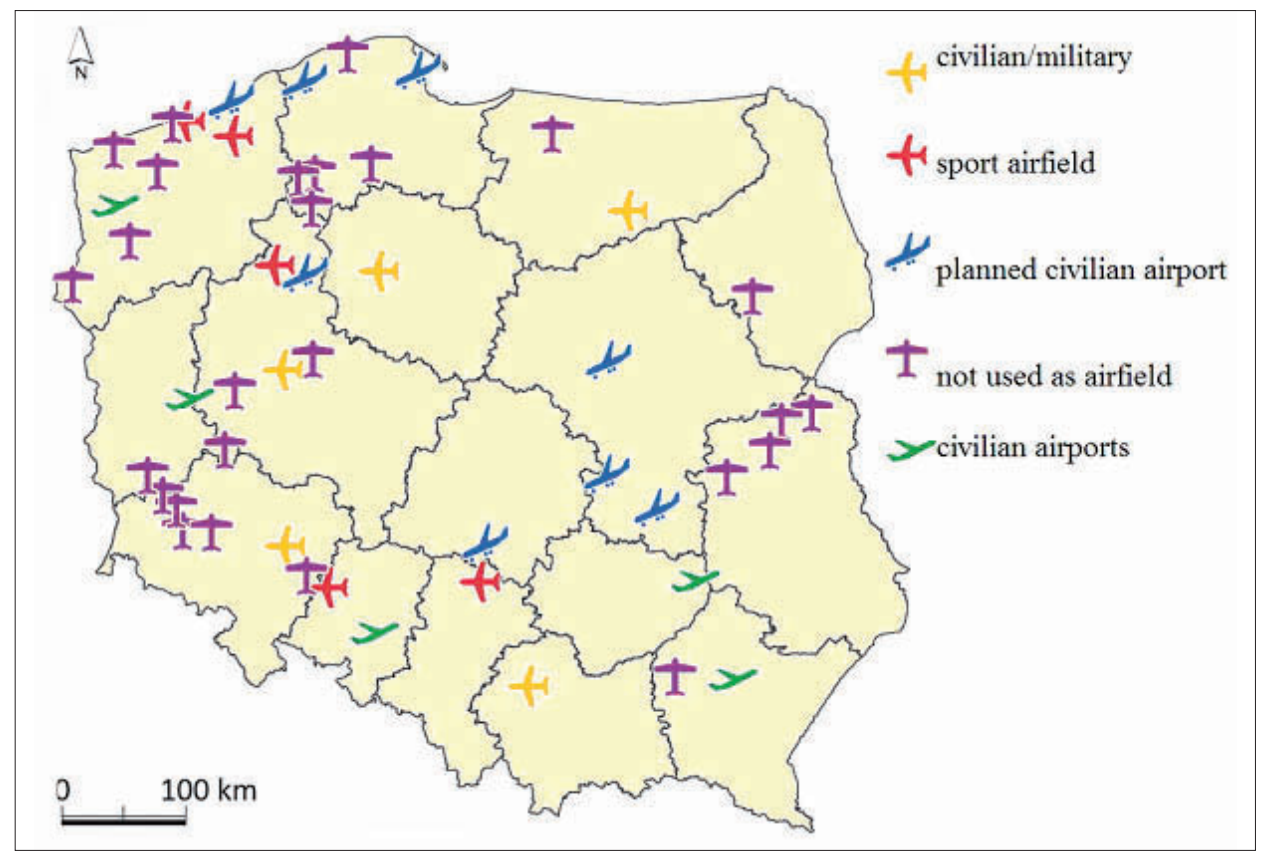

Figure 5. Redevelopment and development potential of former military airfields

5 airfields remain under the Military Property Agency management. In addition, the former military airfields are used for small business activities as aviation facilities, land designated for housing projects, or sports aviation bases.

We currently observe in Poland a growing demand for air transportation services as well as the developmental barriers in the form of inadequate supply of transpor- 
tation services. An analysis of the current situation leads us to formulate a clear conclusion that one of the most realistic approaches in the Polish conditions is to use the military airfield resources that are definitely discontinued by the Air Force or are jointly used by both civilian and military authorities.

"The former military airfields that are not required for that purpose may become the resources for the development of regional and local airports, while their adaptation for sports and recreation facilities may contribute to the development of local airports whose shortage is suffered more and more." (The Airport...2007, p. 44).

On 10 July 2008 the Law of the Management of Certain State Treasury Properties and of the Military Property Agency of 30 May 1996 was amended. The main purpose of that amendment was to accelerate the development of new and expansion of the existing civilian airports. The respective regulation defines the airport and airfield resources that can be used for the development of local or regional aviation facilities (Rozporzadzenie...2008).

According to that amendment, the Governor is entitled to transfer an airfield or part thereof to the local government agencies. The transfer is carried out upon submission of an application to the Minister responsible for transportation. Upon issuance of the respective order, the local government or civil aviation agency must submit their applications to receive the facility within twelve months. The real estates are transferred for perpetual usufruct. Those institutions are also obligated to pass $30 \%$ of income generated from the real estates to the Armed Forces Modernization Fund.

\section{TOURISM AND RECREATION}

Former Soviet and Polish proving grounds are objects of interest to tourists who are enthusiastic about military objects and history. Proving ground tourism assumes many forms that combine contact with nature and local military interests. Various bikes, walking, kayak and other trekking expeditions are organized on such areas. Those types of activities are mostly non-professional. Visits to the military sites are associated with explorations and "discoveries" of interesting objects.

Due to high costs, specific ownership structure and lack of proper transportation and tourist infrastructure, it has not been possible to create any interesting and popular tourist product for post-military areas in Poland.

Former military facilities were turned in about a dozen of Polish towns into sports centres and recreational facilities (Bochnia, Borne Sulinowo, Gołdap, Ełk, Słubice, Kołobrzeg, Jelenia Góra, Gorzów Wielkopolski, Nysa, Garwolin, Brzeg and Słubice).

\section{LAND RECLAMATION}

Demilitarized areas are often suitable for excellent restoration of the natural environment. Devastated areas become specific abandoned idle lands, free of any business activities, reclaimed by nature.

The influence of the former Soviet military units deployed in Poland on nature was documented in detail in the report prepared by the State Natural Environment Pro- 
tection Inspection (Kamieński 1994). Between September 1992 and the end of 1993, the Inspection ordered a group of scholars from the Military Academy of Technology, headed by Colonel Andrzej Spychała, to conduct an evaluation and a detailed inventory of ecological damages in the former garrisons of the Northern Group of the Soviet Army (Krogulski 2001).

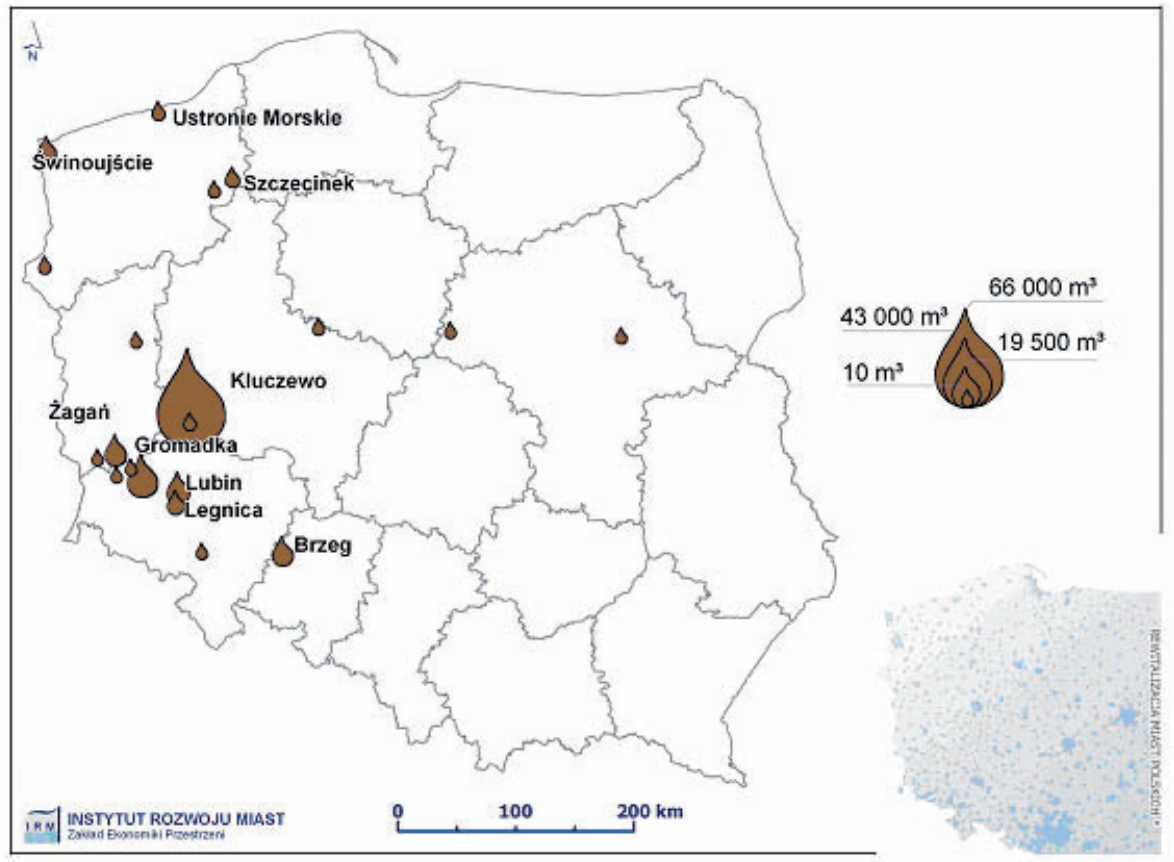

Figure 6. Petroleum pollution in the former Soviet army bases

The value of ecological damages appraised in the analysed facilities, previously occupied by the Soviet Army in Poland, was estimated at that time at 52.2 billion Polish zlotys, or 2.15 billion US dollars (at the exchange rate of January 1994). In total, $86 \%$ of the land was appraised. The soil and underground water recognized to be the most dangerously polluted, mainly by petroleum products (Figure 6), constituted $66 \%$ of all ecological damage areas. Other types of damage in the natural environment included: illegal landfills, forest damages and poisoning and radiating combat weapon contamination. Nearly $1 \%$ of land presented the level of pollution that rendered them improper for any use. A similar conclusion concerns $10 \%$ of underground water (Sprzatanie... 1994).

The majority of lands polluted by the former Soviet and Russian Federation Armies was subjected to extensive land reclamation programmes. They were managed as an independent project until 2000 (and the project was later included in the Government's Strategic Programme). The project concentrated on the liquidation of petroleum product pollution and mine clearing on proving grounds. The resources required for the project were issued by the Ministry of the Natural Environment. 
It was possible to remove the majority of petroleum hazards before 2004. Unexploded shells still present problems (it was found that their quantities were higher than initially estimated).

The interviews and surveys collected in the municipalities where Polish military unites had been deployed allowed us to estimate that those areas were not subjected to any large nature reclamation projects. We should mention, however, that the scale of environmental degradation on such areas was rather small and no large reclamation projects were required.

\section{CONCLUSIONS}

The total surface area of transferred post-military areas amounts to ca. 77,600 ha of which 11,900 ha $(15.5 \%)$ are situated in towns and cities. About 4,000 ha remains to be redeveloped in towns. Those areas and facilities are mostly located in the western regions of Poland: Zachodniopomorskie, Lubuskie and Dolnośląskie. Few areas remain to be managed in other regions.

In total, post-military areas were identified in 218 municipalities (post-Soviet Army areas in 57 and post-Polish Army ones in 161 municipalities), including 134 towns (post-Soviet Army areas in 32 and post-Polish Army ones in 96 towns). 6 towns have the areas which were used by both former Soviet and Polish Armies.

Intensely urbanized areas (former garrisons, with barracks, hospitals, warehouses and fuel depots) have been identified in 107 towns. In total, they occupy about 10,000 ha. In addition, 5 former proving grounds were identified. They are not used by the Armed Forces any more. They occupy 49,900 ha in total. Also, 48 former airfields, with the total surface area of 16,800 ha were identified. Some of them still belong to the defence network, while their civilian portions are recognized to be post-military.

The majority of proving grounds and some airfields were located outside towns, while the majority of barracks, buildings and structures were placed in towns. The most of financial and organizational resources allocated for redevelopment of the post-military areas were spent in towns and cities. 3,455 military buildings were identified in towns, and conversions were completed in 2,144 of them. The basic regeneration directions included the following:

- Building of a new town (Borne Sulinowo)

- Creation of new or regaining of former town boroughs

- Adaptation of former military buildings for housing, education and administrative purposes

- Adaptation of former airfields and proving grounds for capital investment zones, or civilian airports

- Tourist use of post-military areas and land reclamation for nature

As a result of our research, we found that the post-Soviet stock had been redeveloped to a large extent. More than 15 years have passed since the Russian troops left Poland, and many regeneration and reconstruction projects were completed in that period. The completion of those processes is expected to come in 2011. That 
is when the Strategic Plan for Redevelopment of the Former Russian Federation Army Property (Strategiczny...1995) will come to an end. The main obstacle on the way to complete the use of that property is the mismatch of the real estates and the municipal needs (quite often, the barrack complexes of a small-town size are located in rural municipalities). In many cases, the land reclamation costs exceed the potential income from regeneration. One of the common practices has been the conversion of post-Soviet barrack complexes into housing estates, or public administration facilities in some locations. There are only a few examples of municipalities which have failed to redevelop a considerable proportion of buildings (Kłomino-Gródek estate in the Borne Sulinowo commune). Post-Soviet airfields had been considerably remodelled to be converted into local or regional airports. However, in many cases, they present a large potential for capital investments (6 sections of Special Economic Zones) and housing projects. Unfortunately, the aviation facilities were lost in many cases (infrastructure was either stolen or devastated). Land reclamation projects on the former Soviet proving grounds are coming to conclusion.

As to the areas abandoned by the Polish military units, the scale of redevelopment is smaller. Polish garrisons were liquidated only recently, mainly in 2001-2008, and although the scale of the problem is large, the Polish government has not assured any special funds for the redevelopment of that property.

\section{REFERENCES}

Jarczewski, W. (ed.) (2009), Przestrzenne aspekty rewitalizacji—śródmieścia, blokowiska, tereny poprzemystowe, pokolejowe i powojskowe, tom 4, Instytut Rozwoju Miast, Kraków.

Kamieński, Z. (1994), Identification and appraisal of ecological damages caused by the Russian Federation Army Units deployed in Poland, Edited by Kamieński, Z. et al., Warszawa.

Krogulski, M. L. (2001), Okupacja w imię sojuszu. Armia Radziecka w Polsce 19561993, Wydawnictwo von Borowiecki, Warszawa.

Lentowicz, Z., (2009), Tysiące hektarów pod młotek, Rzeczpospolita, (18 czerwca 2009).

Law of Reconstruction, Technical Modernization and Financing of the Polish Armed Forces in 2001-2009 25 July 2001, as later amended.

Rozporządzenie Rady Ministrów z dnia 24 grudnia 2008 r. w sprawie wykazu lotnisk wojskowych, które mogą być wykorzystane na potrzeby lotnictwa cywilnego.

Social and economic consequences of the liquidation of garrisons subjected to the "Programme of reconstruction and technical modernization of the Polish Armed Forces in 2003-2006, with updates for 2003-2008”, 2004, <http://www.kprm.gov.pl> Sprzątanie po Rosjanach, Polska Zbrojna, 1994.

Strategiczny Program Rzadowy: Zagospodarowanie mienia przejętego od wojsk Federacji Rosyjskiej (1995). Ustanowiono decyzją Rady Ministrów 23 maja 1995 r. <Interia, 10 października 2000> 
Szczepański, M. (2005), Polska. Życie po J.A.R. 10-lecie programów zagospodarowania mienia przejętego od wojsk Federacji Rosyjskiej, Rada Programowa do Zagospodarowania Przejętego Mienia i Rekultywacji Terenów Zdegradowanych przez Wojska Federacji Rosyjskiej, Warszawa.

The Airport Network Development Programme (2007).

Wojtyś, A. (2002), Piła mądrzejsza po szkodzie, Polska Zbrojna, 14 (273), (kwiecień 2002). 
http://rcin.org.pl 